\title{
CONVICT THE DEVIANT
}

\section{Masculinity and Rape in Early America}

IN THE LATE EIGHTEENTH CENTURY, THE PROPER EXPRESSION OF MASCULINITY WAS ESSENTIAL FOR CITIZENSHIP AND ACCEPTANCE INTO THE PATRIARCHAL COMMUNITY. RAPISTS WERE CONSIDERED TO BE PRIME EXAMPLES OF UNMANLY DEVIANTS EXPRESSING THEIR SEXUALITY OUTSIDE OF CULTURALLY ACCEPTABLE NORMS. DESPITE THIS, RAPES OFTEN WENT UNPUNISHED OR IGNORED, AS RESPECTABLE AND OFTENTIMES WEALTHY MEN SERVING AS JUDGES AND IN JURIES STROVE TO PROTECT THEIR ACCESS TO WOMEN. THE FEW MEN THEY CHOSE TO PROSECUTE AND EXECUTE FOR RAPE WERE OVERWHELMINGLY MARGINALIZED PEOPLE WHO REFUSED TO CONFORM TO ACCEPTABLE STANDARDS OF MALE BEHAVIOR. THROUGH CRIMINAL NARRATIVES, ACCUSED RAPISTS-OFTEN WITH THE INPUT OF A MINISTER —EXPLAINED THEIR CRIMES IN THE CONTEXT OF THEIR PAST ACTIONS AND CIRCUMSTANCES, AND WARNED OTHERS TO CONFORM TO ACCEPTABLE STANDARDS. THE USE OF CRIMINAL NARRATIVES TO EMPHASIZE THE GENDER AND SOCIALLY DEVIANT BEHAVIORS OF CONVICTED RAPISTS POPULARIZED THE BELIEF THAT IT WAS PRIMARILY UNMANLY OUTSIDERS, RATHER THAN RESPECTABLE PATRIARCHS, WHO COMMITTED SUCH CRIMES. 
In the highly patriarchal context of colonial Massachusetts, the expression of a proper form of masculinity was crucial to one's position in the male community. Rape is a particularly important example of the ways in which masculinity and power interacted, as it expressed gender and sexual deviance, but at the same time, remained unpunished by judges and juries. An overwhelming majority of late eighteenth century men agreed that convicted rapists were not properly masculine, and less respectable men who rejected gender norms earlier in their lives were more believable rapists. Earlier expressions of deviant masculinity influenced the court's decision to convict accused rapists, as it made them less sympathetic to the (presumably respectable) men on juries who decided their fate. Average men saw sexual deviants as more likely to commit rape because they did not belong to the male community that strived to protect one another and the social system from which they all benefitted. Unmanly and sexually deviant rapists, both due to their committing rape and their past actions, were social outsiders who clearly did not accept community standards of behavior and thus threatened the patriarchy.

Criminal narratives or autobiographies of convicted rapists are crucial in highlighting the connections between deviant masculinity, rape, and social order. These criminals detailed their life stories and connected their past transgressions of masculine norms to their rape and imminent executions. A publisher or minister often provided moral commentary or otherwise edited the narratives to emphasize the dangers of sin or socially unacceptable behavior. ${ }^{1}$ They warned other young men to live proper manly lives within the bounds of societal norms in order to avoid becoming rapists themselves.

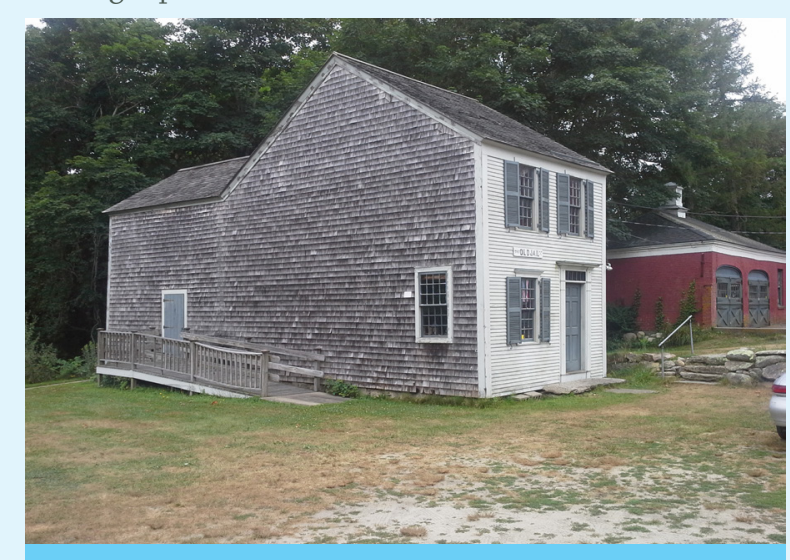

THE OLDEST WOODEN JAIL IN AMERICA, BARNSTABLE, MASSACHUSETTS (COURTESY OF WIKIMEDIA COMMONS)
Most historians have argued that marginal men were more likely to be prosecuted for rape for a number of reasons, including their inability to reformulate coerced sex as consensual and the fact that it was less believable that women would consent to sex with undesirable men. In this paper, I will synthesize this approach with scholarship about masculinity in order to demonstrate that gender performance and sexual behavior were just as central to the construction of certain men as rapists, as was socio-economic status or race.

Historians also largely agree that elite men insisted on retaining privileged access to women, and therefore attempted to restrict lower status men from accessing these women. This resulted in an extremely low rate of executions for rape overall, but ensured that the overwhelming majority of the men convicted of rape were lower class or marginal in some way. ${ }^{2}$ While this is certainly true, there are few scholarly works that analyze the impact of criminal narratives on the achievement of this goal. Elite men's continued focus on certain types of rape cases improved their own access to women. Popularizing the stereotype of the poor, nonwhite, sexually deviant rapist masked their own participation in sexual violence and emphasized women's need for patriarchal protection.

In order to understand criminal masculinity, one must first understand more prevalent and accepted forms of eighteenth-century masculinity. The most respected position to which a man in colonial America could aspire to was that of a patriarch. This sort of man was independent; no one could control him, and he was able to exert control over others, particularly women. ${ }^{3}$ Patriarchs had the authority to use force and intimidation to compel their dependents to obey, but they also had to provide them with protection and support.4 In order to achieve this balance and effectively exert control over others, an ideal patriarch had to be in complete control of both his body and his mind. 5 A man could only become a patriarch or a head of household through financial self-sufficiency. In the eighteenth century, this meant that he had to own his home and land. ${ }^{6}$ At this time, the masculine man became increasingly involved in the activities surrounding his home. While women were responsible for household labor, men controlled important domestic decision-making.?

Not all men could attain this patriarchal manliness, whether by virtue of their personal failings, their socioeconomic status, or their race. However, they could still reach a level of respectability through obedience to manly patriarchs. 


\section{"Through the confessions of convicted rapists, one can see how the rapist connected himself to larger concepts of masculinity and society."}

Low-status men could demonstrate their limited manliness by conforming to the "natural" social order and obeying their fathers, masters, or employers. ${ }^{8}$ This idea, while not overwhelmingly popular during the Revolution, gained increasing support during the constitutional period, as Federalists promoted the idea that all citizens, while independent, still needed to be under the control of more competent and educated men who had the ability to govern effectively. ${ }^{9}$ While many men accepted or at least lived in accordance with this model, some slaves believed that the best way to reclaim their masculinity was through rebellion or by assaulting their masters as doing so demonstrated their own manly independence and power. ${ }^{10}$ One can see examples of idealized independent masculinity, as well as hierarchical obedience, in criminal narratives, through the rapists' actions as well as in the life paths they rejected.

The narratives of these convicted rapists existed in a context in which very few women reported rapes, and of these reported cases, very few resulted in convictions. ${ }^{\text {II }}$ Rape was connected to lesser sexual sins and thus very difficult to differentiate from ordinary illicit sex. ${ }^{12}$ Eighteenth-century men and women expected that men would use violence and force in sex regardless of a woman's consent. ${ }^{13}$ Masculine sexuality was dominating and aggressive (although ideally, men would practice restraint), while feminine sexuality was submissive and dedicated to the man's pleasure. ${ }^{14}$ The belief that a woman, if she were respectable, would feign resistance even in a consensual sexual encounter made it even more difficult for women to prove the occurrence of a rape. ${ }^{15}$ Eighteenth-century jurists believed that women could and would easily lie about rape. Consequently, women needed to satisfy a number of criteria in order to be understood as legitimate victims, as did their rapists to appear as believable aggressors. ${ }^{16}$

Often, claims of rape did not lead to convictions and executions. The men who published criminal confessions were exceptional cases that did not fit the norm in New England at this time. Generally, men were unwilling to execute other men for sexual crimes, even in situations of clearly nonconsensual intercourse. ${ }^{17}$
Women rarely reported rapes because rape victims did not often receive justice in the courtroom and they faced severe consequences if their communities did not believe their accounts. ${ }^{18}$ Because of cultural assumptions about force in consensual sexual relationships, accused rapists often defended themselves by asserting that the sex was consensual, that the female accuser did not physically struggle, and that their accuser was of poor moral character (and was thus more likely to consent to sex). ${ }^{19}$ While there were obstacles to prosecution, courts did accord respect to the testimony of certain victims, particularly if they were white and strangers to the rapist. ${ }^{20}$ Courts would most likely believe a woman if she accused someone with whom they thought she would never consent to sexual relations. ${ }^{2 I}$

Rapists who fit this description of the sexually undesirable deviant were among the exceptions who wrote criminal narratives. Cultural representations of rape portrayed outsiders, including men of color, men of lower social status, foreigners, and non-Protestants, as more plausible rapists. Such portrayals impacted the types of men initially brought to trial as well as their conviction rates. ${ }^{22}$ Because these men did not submit to the control of a normatively masculine patriarch, rapes committed by them not only threatened the safety of women, but also challenged the dominance of the patriarchy itself. ${ }^{23}$

The greatest concern in the prosecution of rape cases was not the disruption that rape caused in the lives of women, but rather, as Thomas Foster has argued, its impact on patriarchal authority and orderly social relations. The rapist's primary crime was going against male hierarchical structures and social order, not harming the victim. ${ }^{24}$ It is for this reason that rapes committed through patriarchal power (the rapes of slaves and children, for example) often did not go to trial. ${ }^{25}$ Through the confessions of convicted rapists,one can see how the rapist connected himself to larger concepts of masculinity and society.

Although one cannot take the confessions of convicted rapists at face value, statements such as these can provide valuable insight into both how these men viewed them- 
selves and, perhaps more importantly, what they believed their community members wanted to hear. These confession narratives often followed a similar format wherein the accused connects the crime for which he was executed to socially unacceptable behaviors. After his conviction, he repents, asks God for forgiveness, and calls on others to refrain from immoral activities in order to save themselves from the same fate. The formulaic nature of these narratives make it difficult to ascertain the sincerity of these men's regret about their actions, but a close examination and comparison of these documents reveals differences in style and content that gives some insight into how these convicted rapists understood their crime.

One must be wary not only of the influence of others on these narratives but also of the rapist's own motives for publishing their life story. In many cases, ministers wrote these confession stories with the convict's input, and as a result, the final product often reflected the ministers' interests in promoting order and religion. ${ }^{26}$ Because the narratives are supposedly first person accounts from the rapists themselves, one cannot expect them to be objective accounts of facts, but rather reflections of the authors' perceptions of the world. ${ }^{27}$

These criminal narratives originated in New England in the late seventeenth century, but they began to focus more on sexual crimes toward the end of the eighteenth century. ${ }^{28}$ While earlier narratives paid more attention to criminal submission and did not go into much detail about the criminal's life, these later narratives placed more importance on childhood development and, to some extent, celebrated the criminal's defiance of authority. ${ }^{29}$ This was also a time of increased popularity of criminal confession narratives. In contrast to the late eighteenth century, whenthey were published in conjunction with execution sermons, publishers began to sell them independently as broadsides and chapter books. ${ }^{\circ}$ Criminals described their lives and characters in an attempt to explain why they committed their horrific crimes. ${ }^{3}$

These autobiographies functioned as both warnings and "sensational human interest stories." ${ }^{2}$ Even the earliest criminal confessions strove to satisfy a "hunger for sensationalism and story" through the use of taboo subject matter and vivid imagery. ${ }^{33}$ These narratives allowed criminals to brag about their sexual exploits and their adventurous lives. ${ }^{34}$ Despite this literary function, the ministers and publishers who guided their production also desired to impart moral lessons to their readers. This is especially true of the confessions made by black criminals, who often ended their narratives by warning other black people to remain obedient slaves, while the confessions of white criminals served as warnings to the entire community. ${ }^{35}$ Black criminals' examples also promoted an association between blackness and criminality. This association would ideally deter white criminality, as the ministers assumed that white people would recoil from behavior associated with black people. ${ }^{36}$

In the following pages, I will examine the confession narratives of three different men who committed their crimes and were executed in Massachusetts between I768 and I779. They came from different backgrounds and lived very different lives, but all of them possessed deviant masculinities that contributed to their convictions and executions for rape. These men, as outsiders, did not have the social power to use sexual force and violence against women without consequences. ${ }^{37}$ While these cases were exceptions, as very few rapists were successfully prosecuted, they are valuable sources that recount the taboos and behavior that constructed certain men as believable rapists at a time when very few men were seen as such.

Each of these cases represents a different type of man who was convicted of rape and also a different sort of deviant

$$
\begin{array}{r}
\text { "While these cases were exceptions, as very few rapists } \\
\text { were successfully prosecuted, they are valuable sources } \\
\text { that recount the taboos and behavior that constructed } \\
\text { certain men as believable rapists at a time when very few } \\
\text { men were seen as such." }
\end{array}
$$


masculinity that corresponded to his outsider status. The first case, that of Arthur, represents one of the most typical cases of convicted rape: the rape of a white woman by a black slave. This account portrays him as a rebellious slave, unmanly by virtue of being black and dangerous because he rejected the constraints of white society. Robert Young's case is also fairly typical because he was a British soldier, which designated him, in American eyes, as more likely to be a rapist and sexual degenerate..$^{8}$ Brian Sheehen does not fit so easily into the era's stereotypes of sexual predators. While he was disreputable and sexually deviant, he could appear superficially to be an ordinary white man. His case is relevant not because he is representative of an obvious subset of men who were more believable rapists, but because in his narrative he or a ghostwriter made a point to emphasize his unmanliness, sexual deviancy, and outsider status-characteristics that eighteenth-century Americans did not consider essential to his identity. The cases of these three different cases of rapists show the importance of constructing rapists as outsiders.

Arthur was a twenty-one-year-old runaway slave who was executed in 1768 for the rape of a white widow, Deborah Metcalfe. Although black-on-white rape did not automatically warrant the death penalty in the colonial period as it did after the Civil War, the majority of the men executed for rape between I700 and I820 were black. ${ }^{39}$ Black rapists like Arthur were simultaneously rebellious slaves and examples of "human depravity," and thus threatened white masculinity itself. ${ }^{\circ}$ The rape of a white woman by a black man indicated a sense of manly independence that was highly threatening to white men living in a race-based hierarchy. ${ }^{4 \mathrm{I}}$

When reviewing Arthur's narrative, one must understand his actions within the context of the slave system that Arthur actively rebelled against. His community saw blackon-white rape as a form of resistance to slavery; Arthur's story served as a confirmation of this assumption. His rape of a white woman was only the last of his rebellious actions in a lifetime of resistance to his masters' control..$^{42}$ Parts of his story even seem to glorify his past misdeeds and sexual promiscuity, although the narrative (either through Arthur's change of heart or a minister's intervention) ultimately rejects this rebellion in favor of orderly white control. ${ }^{43} \mathrm{He}$ subverted his masters' authority by stealing from them, running away, and otherwise living his life contrary to white Christian social norms. While he claimed that he

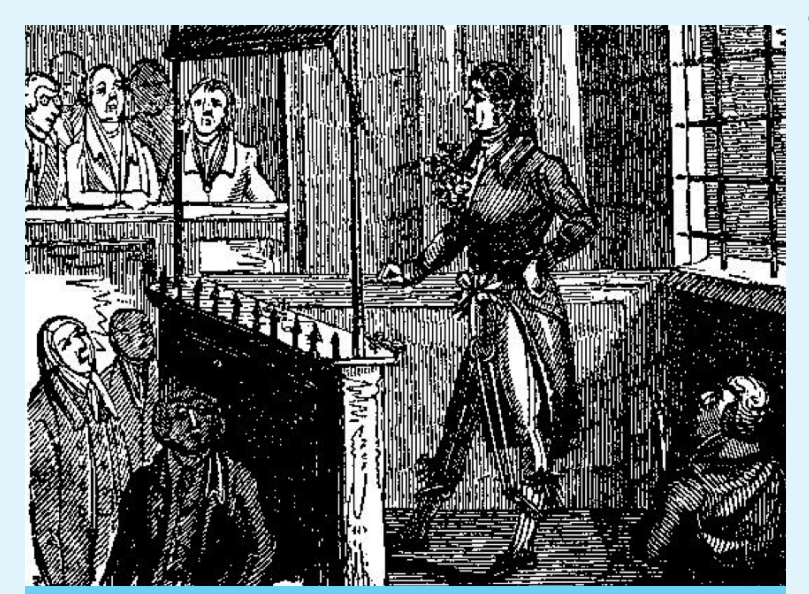

AN EARLY DEPICTION OF A MAN ON TRIAL IN THE LATE 18TH CENTURY (COURTESY OF WIKIMEDIA COMMONS)

was well treated by one of his masters, he continued to drink, have illicit sexual relations, and steal, thus contributing to the stereotype of the degenerate black man. At this time, New Englanders believed that by committing a small sin, a person became more willing and likely to commit a more serious transgression, particularly with regard to sexual sins like fornication and rape. ${ }^{44}$ His race added another dimension to his crimes, as it was worse for a black man to disobey his Christian master whose efforts to Christianize and control his slaves would deliver them from Hell. 45

Arthur recounted his sexual past as an explanation for his rape of Metcalfe. Like his contemporaries, he "regarded rape and attempted rape as the end point on a continuum of sexual offenses." ${ }^{6} 6 \mathrm{He}$ had sex with women of different races, including white and Native American women, and portrayed himself as a man unable to control his lust, which fits into the narrative of the sexually aggressive black man common in New England at the time. ${ }^{47}$ His Native American sexual partner, "who like the rest of her sex was of a very fruitful Invention," encouraged him to run away, and it was only because this woman was unavailable that Arthur decided to rape Deborah Metcalfe. Other accounts of rape in colonial New England also portrayed non-white women as accomplices to the rape of white women, and Native Americans in particular as leading white and nonwhite men away from God..$^{8}$ This part of Arthur's narrative portrayed rape as a crime of sexual desire, which fit into the common eighteenth century understanding of the crime. 49 
At the end of his confession, Arthur warned "those of my own Colour, as they regard their own souls, to avoid Desertion from their Masters, Drunkenness and Lewdness." 50 This admonition connects directly to the very beginning of his life story, where he recalled his very first crime that led him down a path of sexual misconduct and crime: running away from his master. He instructed other black people to obey their masters and accept white authority in order to live a long moral life. Black people should not desire freedom and instead be content with their lives of obedience to white masters; Arthur's story was an example of the consequences of desiring liberty. ${ }^{51}$ He associated rape with a broader rejection of white authority, although his account of the actual act of rape did not examine the racial dynamic of a black-on-white rape, as would have been the case in the nineteenth century. ${ }^{52}$ In his warning, Arthur connected his fate to racial power dynamics, as he blamed his own rebellion for his execution. In this narrative, the rape was only one of a long list of crimes that he committed against white people and white authority.53

\section{"In his warning, Arthur connected his fate to racial power dynamics, as he blamed his own rebellion for his execution."}

While it is impossible to know if Arthur truly accepted white domination and repented for his crimes against white people and the white-dominated social order, it is quite possible that the ministers who helped him write this confession encouraged him to frame his crime in this way to discourage other black men from subverting white men's authority. Arthur thanked Reverend McCarty for his "unwearied pains... to awaken me to a proper sense of my miserable and wretched condition," and it is likely that this minister coached his testimony. ${ }^{54}$ It is difficult to believe that a man who spent his whole life avoiding slavery and disobeying his masters would alter his views so dramatically, even when confronted with death.

Another preacher, Aaron Hutchinson, also used Arthur's story to warn others, particularly black people, against following Arthur's rebellious example. ${ }^{55}$ Reverend McCarty's own sermon following Arthur's execution was highly sympathetic to Arthur and preached pity and forgiveness. ${ }^{56}$ He emphasized a lack of control over one's fate and God's forgiveness. Neither preacher reveled in the execution of a black man for the rape of a white woman, and even the victim herself did not want Arthur to be hanged.57 These ministers portrayed Arthur's execution as an essential both punishment and a warning to other black people to stay in their place. While an individual black man's execution for rape was regrettable, it was necessary to maintain a social order that had a considerable stake in white supremacy..$^{8}$

Another man with a far different, yet nevertheless marginal, position in colonial Massachusetts's social hierarchy was Robert Young, an Irish-Catholic deserter of the British army who was executed in I779 for the rape of a child. Like Arthur, Robert Young saw this rape as the result of a life of sexual immorality and sin, a view that ministers of this time professed.59 From his youth, Young claimed, he "was much inclined to the company of women." ${ }^{60}$ He repeatedly mentioned his seduction and ruination of numerous women throughout his life and made it clear that he would go to extreme measures to satisfy his lust, something that placed him outside of the community of respectable men. ${ }^{61}$

He saw his crime in a broader context of sexual deviancy and a lack of regard for women. Every place he went, Young "studied to deceive the fair sex, and betrayed a young woman in each of them," an indication of his talent for seduction. ${ }^{62}$ Although at the end of the narrative, he predictably repented and asked other young men to avoid alcohol and lewd women, throughout his story, he bragged about his sexual conquests and did not show any remorse for his negative impact on many women. ${ }^{63}$

Regardless of his previous sexual exploits, Young's history as a British soldier immediately associated him with sexual immorality and corruption. ${ }^{64}$ He joined the army because of his excessive sexuality. When he still lived in Ireland, Young's employer threatened to tell his parents about his immoral activity. Young refused to give up alcohol and illicit sex and devote himself to business, choosing instead to enlist. He even cited the moment he joined a British regiment as the time when he "gave myself up to all manner of debauchery." ${ }_{5}$ Americans saw British soldiers as rapists and, like black men, they were overrepresented in print accounts of rape. ${ }^{66}$ The rape of innocent American 


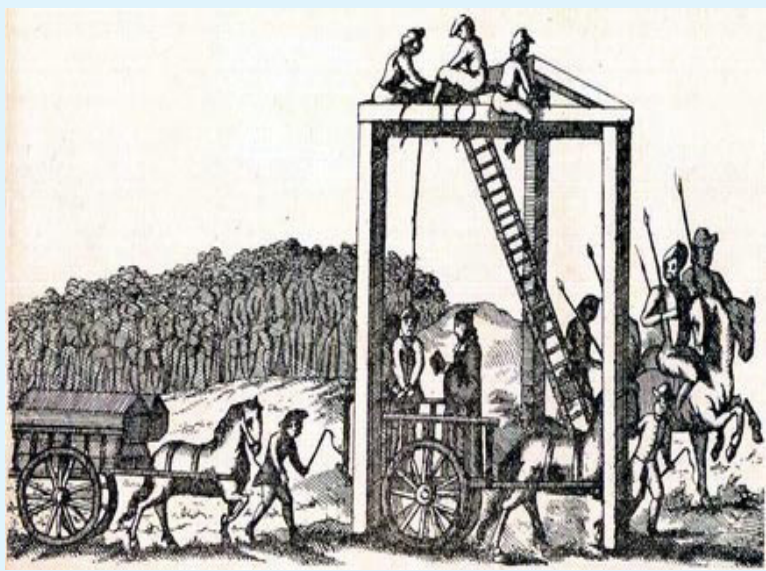

ILLUSTRATION OF THE TYBURN GALLOWS (COURTESY OF WIKIMEDIA COMMONS)

women and girls by the lecherous agents of a corrupt political system was a powerful tool that Americans used to justify their disregard for British authority. ${ }^{67}$ While this may not have been the prime motivation for Young's conviction and execution, this unforgiving image of British soldiers nevertheless impacted how members of the jury and public thought of Robert Young.

According to literary scholar Keith Lawrence, Young's sexual behavior reflected his lack of regard for "communalism." Not only was he an outsider in New England, but his actions also showed his contemporaries that he was also a moral outsider, as he did not care what impact his actions had on the community. ${ }^{68}$ This disregard was particularly important at a time when community regulation of individuals, particularly with regard to sex, was a crucial foundation of societal order. In the previous century, the supervision and control of young people likely made rape less common, and although societal control was weaker in the eighteenth century, town leaders were unfriendly towards outsiders who took advantage of their daughters and sisters. ${ }^{69}$ While other men had communities and families that protected them from prosecution for rape, Young had no one to defend him. $7^{\circ}$ His marginal status prohibited him from manufacturing consent in his sexual exploits..$^{71}$ Rapes committed by lower status outsiders and transients whom patriarchs could not effectively monitor "signaled the disruptive effects of geographic mobility" on social order. ${ }^{72}$ A lack of familial and social connections put Young outside of the community of respectable men and, although he was still a man, Young's identity as a poor, sexually deviant, transient army deserter served as a threat to patriarchy. ${ }^{73}$ Like Young, the majority of the men convicted for rape were "outsiders or marginal men" who threatened to bring disorder to established patriarchs. ${ }^{74}$

Ultimately, Robert Young portrayed himself as a man unrepentant and unconcerned with the women he harmed. He even blamed his early associations with lewd women for his drinking problems; while he was originally "an absolute hater of all sorts of strong liquor," once he began to associate with "lewd women," he "learned to drink to excess." $75 \mathrm{He}$ paid noticeably little attention to the rape that would lead to his death. Instead, Young focused more on his young victim's older sister, who was also his fiancée, a woman he "loved without deceit." He claimed that he wanted to stay faithful to his fiancée, Anne Green, but he was incapable of restraining his sexual desires. He did not reflect on Jane Green, his eleven-year-old victim, but instead apologized to Anne. He did not see his victim or the women who he seduced as people whose feelings and pain were important, but rather as vehicles for his sexual desire. Nor did he truly have any regard for Anne Green, as evidenced by his rape of her sister. ${ }^{7}$

Although his marginality in colonial New England was partially attributable to his poverty and hidden status as an army deserter, Young's confession mainly focused on how his sexual behavior differentiated him from the rest of society. While one can understand this focus as bragging over past sexual conquests, it shows the connection between unrestrained sexual urges and rape both in Young's eyes and in the eyes of readers. This narrative, along with others like it, simultaneously drew from and reinforced this cultural assumption. It emphasized the nature of rape as a crime committed by unmanly social undesirables unable to control their lust, rather than by the powerful men who were able to use their positions in society to redefine their own coercive sexual actions as consensual. ${ }^{77}$

Robert Young's case is particularly interesting because in addition to his short autobiography, he also wrote a poem recounting his life and crime. This poem contains many of the same themes that he wrote about in his confession. He placed responsibility for his fate on his earlier life of sin, his lack of regard for religion and his inability to control his lust. Throughout the poem, he warned other men to avoid a sinful life. ${ }^{78}$ While in his confession a reader may even see the appeal of living as Young did, this poem was 
9 more religious in nature and emphasized Satan's destructive role in his life, as it was "the grand deceiver" who "led [Young] to commit a horrid crime." 79 Young approached his life differently in this poem, to make himself appear more pitiable. He was a young man "in blooming life" who was forced to "write these lines in a gloomy cell" and come to terms with his impending death. ${ }^{80}$ It is primarily a warning to other men not to follow in his path, as it could only lead to unhappiness, as well as a plea for pity and sympathy. While this poem makes it appear as though Robert Young saw his execution as inevitable, it also shows that he still wanted others not to think the worst of him and perhaps even come to his aid and petition for a commutation of his sentence. ${ }^{81}$

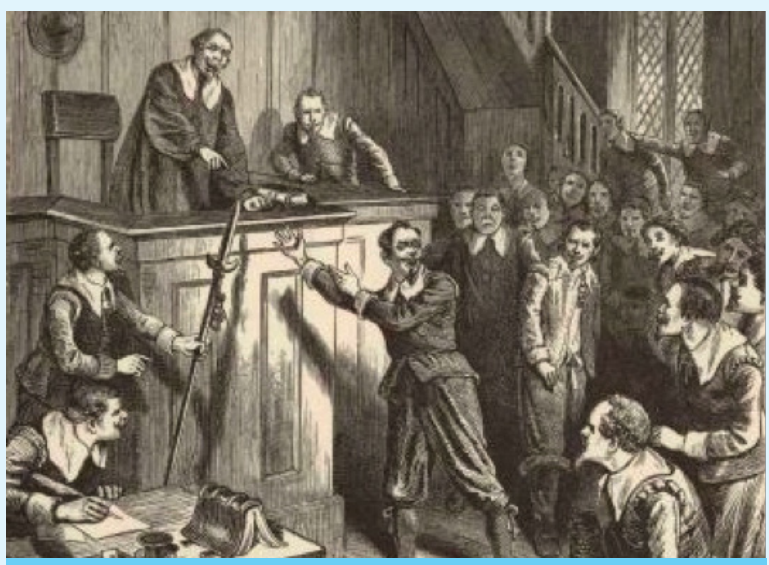

AN EXAMPLE OF AN 18TH CENTURY TRIAL, SIMILAR TO THE ONE THE DEFENDANTS IN THIS STUDY FACED (COURTESY OF WIKIMEDIA COMMONS)

The 1772 case of Brian Sheehen is another example of a marginal and unmanly man's conviction for rape. Like Young, Sheehen was immediately an outsider in New England society upon his arrival, as he was raised Catholic in Ireland. When he came to Massachusetts for work, he hated attending church with his employer's family, and he performed his religious duties "with careless and reluctance, as being in a different way from what he had been used to," which Sheehen identified an example of his immorally. ${ }^{82}$ Because eighteenth century New Englanders considered devotion to Christianity a bulwark against sexual violence, Sheehen's refusal to worship properly could have explained his crime to others. ${ }^{8}$ His lack of piety (specifically worship in one of the "right" churches) immediately made him less sympathetic in the eyes of his
Protestant neighbors. ${ }^{84}$ Additionally, his reluctance to attend church with his employer's family marked him as a disobedient servant and, thus, "a rebel against law and proper social ordering." ${ }^{85}$

His sexual behavior, although not so brazen as that of Robert Young, marked Sheehen as a failed patriarch who differed from respectable men. Although he was married and had a child, he chose a sexually immoral wife whom he later learned was also married to another man. ${ }^{86}$ In the eighteenth century, a husband was usually at fault for his wife's infidelity because it showed his failure as both a patriarch (who was supposed to be able to control his dependents) as well as a sexual partner (because he was unable to completely sexually satisfy his wife). ${ }^{87}$ Unable to properly control his wife, Sheehen left her and his child after nearly killing his wife's second husband. Sheehen may have intended for this story to gain him sympathy as a man wronged by a sexually deviant woman. ${ }^{88}$ However, his account of his wife's sexual behavior likely harmed his reputation and set him apart from more reputable men who successfully governed their families.

In addition to his religion and disreputable family life, Sheehen admitted that he was infamous for his "wicked profligate" character. ${ }^{89}$ While a bad character could mean any number of things, as he did not define his specific actions in great detail, the inclusion of these elements in Sheehen's narrative shows that bad character and disreputability were just as important for the men who were charged with rape as they were for the women who filed charges..$^{\circ}$

In contrast, Brian Sheehen's victim was a reputable married mother who suffered physical injuries and cried out for help. For members of this community, this assault was a clear case of a disreputable, irreligious outsider's rape of a reputable woman. The narrative is different from many others, as it focuses a considerable amount of attention on the victim and the actual act of rape, as Sheehen recounted the events of the night in detail..$^{15}$

The Attorney General proclaimed that he had never seen a clearer case of rape than this one. Not only was the woman respectable and the physical act fulfilled all of the necessary legal requirements to be considered a rape, but Sheehen had an admittedly bad reputation and he was an outsider in the community. Brian Sheehen was the perfect example of degenerate manhood: he was an Irish Catholic, he had 
previously been in jail, and he had no family ties or dependents. ${ }^{2}$ While Arthur and Robert Young were threats because they operated outside of and in opposition to patriarchy, Brian Sheehen tried to achieve respectable masculinity but was ultimately a failure of a man. This case reveals the importance of a man's failure to fulfill masculine ideals to the public's image of him as a criminal.

In the time between his conviction and when this narrative was published, Sheehen claimed to renounce his Catholicism and show an interest in proper Protestant religion, but it is unlikely that his conversion was authentic given the religious function of these confessions. The man, likely a minister, who helped Brian Sheehen put together this autobiography, would clearly have used this occasion to bring as many sinners as possible to Christ. ${ }^{93}$ There was no better example than a sinning Catholic to show that anyone could find the true religion.

Despite their differences, all of these confessions follow a similar format and contain many of the same forms of gendered behavior. Each of these narratives conform to societal assumptions about rape. The convicted rapists all represent a rejection of or a failure to attain a prescribed masculine identity. From the first lines of their narratives, it is clear that they are disreputable men. Arthur was a alcohol, and the infidelity of Brian Sheehen's wife humiliated him and ruined his efforts to be a proper patriarch. All of these components of the narratives signal that these men were marginal and outside of the bounds of acceptable male behavior. ${ }^{95}$

These autobiographies also contain examples of proper patriarchal and masculine behavior to contrast with the condemned rapists. All of these men scorned society through their rejection of the kind and forgiving patriarchs who gave them many opportunities to live respectable lives. Even after he ran away for a year, Arthur's master "received [him] kindly;" Brian Sheehen's employer tried to save his soul and bring him to Christ despite his lack of interest; and Robert Young reacted to his early employer's and parents' concern over his illicit sexuality by enlisting in the British army and leaving Ireland. ${ }^{96}$

At the ends of their lives, upon reflection of their misdeeds (or at the behest of the others who contributed to the writing of these narratives and wanted to put forth a message promoting community order and stability), these men accepted ministerial authority through repentance. Although their disobedience and lack of respect for patriarchs had only brought them pain and hardship in this world, their eventual acceptance of patriarchal authority by apologizing

\section{"While a modern reader may associate sexual aggression with rape, to law-abiding men as well as these criminals, this powerful sexuality was the most socially acceptable part of these narratives."}

slave, the lowest position in colonial New England's social hierarchy, and Sheehen and Young were Irish Catholics, religious deviants and ethnic outsiders. Throughout their lives, these men exhibited unchristian behavior through fornication, indulgence in alcohol, theft and deception. Their inability to control themselves and their willingness to go to extremes to satisfy their desire showed their lack of masculinity. ${ }^{94}$ While these narratives primarily placed the blame for their fates on the criminals themselves, they also employed female temptresses who hastened their path to sinfulness. Arthur ran away with the aid of his Native American mistress, women taught Robert Young to enjoy and thanking ministers for reforming them, presumably would help them find peace in the next life.

The average eighteenth century man could likely identify with these criminals and the patriarchs they rejected. Because these narratives functioned both as moral warnings and sensational adventure stories, men could simultaneously identify with the criminals, feel superior to them and use their story as a cautionary tale. ${ }^{97}$ These criminals exhibited what Thomas Foster called a "masculine counter-norm" of individuality that readers might have considered legitimate..$^{8}$ Although they were unable to restrain 
i themselves, as good and masculine men would, their aggressive sexuality was typical and virile. ${ }^{99}$ While a modern reader may associate sexual aggression with rape, to lawabiding-men as well as these criminals, this powerful sexuality was the most socially acceptable part of these narratives. ${ }^{100}$ They all clearly showed an intense desire to have a woman, both as a sexual partner and as a dependent they could control. Although they showed no indication of wanting to protect and provide for a woman, they did accept certain aspects of their expected role as patriarchs. Arthur sexually mastered his "squaw," Robert Young planned to marry Anne Green, and Brian Sheehen was already married and had a son. Just as respectable men would, these rapists used women's bodies to assert their masculine identities. But in this case, because they did not have women readily available to them to satisfy their lust, they instead resorted to rape. ${ }^{\text {Ior }}$ For the readers of these confession narratives, these qualities indicated that these rapists were masculine, at least to an extent, and they could thus identify with these "anti-heroes." ${ }^{\text {"102 }}$

At the same time, however, a critical component of all of these narratives was the rapists' lack of other markers of masculinity, a factor that considerably impacted the outcomes of their lives. It made them more believable rapists, precluding any sort of community defense, and increasing the feasability of a rape accusation. For example, while they may have exhibited a desire to control women and families, none of these men cared for dependents. Arthur had many sexual partners but, because he was a slave, could never have a socially acceptable family or dependents. Robert Young showed some interest becoming a husband and father with community roots, but he sabotaged his own efforts at achieving an appropriate masculine identity by raping his fiancée's sister. Brian Sheehen came closest to approaching respectable masculinity, as he was married and had children, but his wife's infidelity brought his manhood into question. ${ }^{103}$ Because a man's respectability as a citizen was tied to his marital status and possession of dependents, the lack of a traditional family life among these men at the time of their trials made them particularly suspicious. ${ }^{104}$ Their sexual behavior was, in the eyes of other eighteenth century men, linked to this lack of family life because they did not have the "self- mastery" necessary to head and maintain an orderly household. And because they were not properly married, their masculine sexual energy could only be directed towards immoral purposes. ${ }^{105}$ Their bachelor status, even before they were accused of rape or any of the details of their sex lives became public knowledge, made them suspected sexual deviants.
These men could not be proper husbands because of their lack of self-control and because they were not husbands, they had no proper outlet for their sexual desires. ${ }^{\text {Io6 }}$

These rape narratives indicate that accused rapists knew that their lifestyles did not meet the standards of respectable male behavior. Even accounting for the influence of ministers, these rapists' lives contradicted social norms in almost every way. They were not acceptable husbands and fathers, they were not independent householders, and they did not exercise restraint in their sexual lives. ${ }^{107}$ Their lack of masculinity precluded these men from full acceptance into the male community and made them outsiders in an extremely community-oriented society. Because male sexuality was naturally aggressive, men either needed to be able to control themselves or be under the protection and control of a man who could. Convicted rapists both proved themselves incapable of self-mastery and were, at the time they committed their rapes, independent and uncontrolled. This understanding of rape made Arthur, Robert Young and Brian Sheehen appear more likely to be rapists, and certainly contributed to their deaths.

By telling their stories (or having their stories told) in these criminal autobiographies, these rapists contributed to the conception of a rapist as a deviant outsider. Because these narratives reached such a large audience, they were extremely effective in reinforcing popular understandings of rape and solidified the association between certain unmanly men and rape. This made it even more difficult for people to accept patriarchs and elite men as rapists, as the sexual deviance and outsider status associated with rapists were not consistent with the image of a respectably masculine patriarch.

By blaming rape on unmanly, low-status men, elites could continue to coerce women into sex without understanding these sexual encounters as rape. It was not until second wave feminism that women began to question this assumption and demand a change in how society views sexual assault. Even today, it is difficult for people to conceptualize of ordinary men as rapists. Many still assume that outsiders, modern versions of Arthur, Young and Sheehen, are responsible for the majority of rapes when, in reality, women are most vulnerable to attacks by acquaintances, friends, family, and romantic partners. ${ }^{108}$ Criminal narratives played an important role in reinforcing the construction of rapists as false men, and thus allowed real rapists, both past and present, to escape suspicion. 


\section{ENDNOTES}

I. Williams, "Rogues, Rascals and Scoundrels." I983, 8, Io.

2. Hambleton, “'Playing the Rogue:' Rape and Issues of Consent in Seventeenth Century Massachusetts.” 200I, 37.

3. Ditz, "The New Men's History and the Peculiar Absence of

Gendered Power: Some Remedies from Early American Gender

History," 2004, II-I2.

4. Brown and Brown, The Hanging of Ephraim Wheeler, 2005,

I34; Foster, Sex and the Eighteenth-Century Man, 2006, 23.

5. Kerber, et al. "Beyond Roles," I989, 573.

6. Brown and Brown, The Hanging of Ephraim Wheeler, 2005,

I87-I88; Lindman, “To Ravish and Carnally Know." $2000,395$.

7. Leverington, "Domesticating the Hero." $2007, \mathrm{I}_{2} 2$.

8. Slotkin, "Narratives of Crime," I973, 7.

9. Osborne, "Constituting American Masculinity," 2008, II3.

Io. Rindfleisch, "What it Means to Be a Man," 20I2, 86I.

II. Block, "How Should We Look at Rape in Early America," 2006, 604.

I2. Hambleton, "Playing the Rogue." $2001,42$.

I3. Hambleton, "Playing the Rogue." 200I, 29.

I4. Foster, Sex and the Eighteenth-Century Man, 2007, 68;

Hambleton, "Playing the Rogue." 200I, 29; Block, Rape and

Sexual Power in Early America, 2006, 29.

15. Block, Rape and Sexual Power in Early America, 2I.

I6. Block, Rape and Sexual Power in Early America, I6I.

I7. Hambleton, "Playing the Rogue." 200I, 28; Goodheart, "Rape, race and capital punishment in Connecticut to I830.” 2012, 63. I8. Brown and Brown, The Hanging of Ephraim Wheeler, 200I, I34; Snyder, "Sexual Consent and Sexual Coercion in Seventeenth- Century Virginia in Sex without Consent: Rape and Sexual Coercion in America," 200I, 46.

I9. Hambleton, "Playing the Rogue." 200I, 27.

20. Goodheart, "Rape, Race and Capital Punishment in Connecticut to I830." 2012, 62, 77; Cohen, "Social Injustice, Sexual Violence, Spiritual Transcendence: Constructions of Interracial Rape in Early American Crime Literature, I767-I8I7," I999, I8.

2I. Block, Rape and Sexual Power in Early America, 2006, 52.

22. Goodheart, "Rape, race and capital punishment in Connecticut to 1830." 2013, 77; Foster, "Sex and the Eighteenth Century Man," 20I2, 57; Block, "How Should We Look at Rape in Early America?" 2006, 609.

23. Foster, Sex and the Eighteenth Century Man, $2007,59$.

24. Foster, Sex and the Eighteenth Century Man, 2007 54-56.

25. Block, "How Should We Look at Rape in Early America?" 2006, 6ro.

26. Williams, "Rogues, Rascals and Scoundrels," I983, Io. 27. Brown and Brown, The Hanging of Ephraim Wheeler, 2005, I57.

28. Brown and Brown, The Hanging of Ephraim Wheeler, 2005, 42; Slotkin, "Narratives of Negro Crime in New England," I973, I8.

29. Brown and Brown, The Hanging of Ephraim Wheeler, 2005, I57; Williams, "Rogues, Rascals and Scoundrels," I983, 6. 30. Williams, "Rogues, Rascals and Scoundrels," I983, 8
3I. Williams, "Rogues, Rascals and Scoundrels," I983, II. 32. Brown and Brown, The Hanging of Ephraim Wheeler, I973, I56.

33. Williams, "Rogues, Rascals and Scoundrels," I983, 7. 34. Cohen, "Social Injustice, Sexual Violence, Spiritual Transcendence," I999, 504.

35. Slotkin, "Narratives of Negro Crime in New England," I973, II; Williams, "Rogues, Rascals and Scoundrels," I983, 7. 36. Slotkin, "Narratives of Negro Crime in New England," I973, 25

37. Block, Rape and Sexual Power in Early America, 2006, 74.

38. Foster, Sex and the Eighteenth-Century Man, 2007 , I8.

39. Block, Rape and Sexual Power in Early America, 2006, I63. 40. Block, Rape and Sexual Power in Early America, 2006, I27; Foster, Sex and the Eighteenth-Century Man, 2007, I3I.

4I. Foster, Sex and the Eighteenth-Century Man, 2007, I39.

42. Block, Rape and Sexual Power in Early America, 2006, I49. 43. Goodheart and Hinks, "See the Jails Open and the Thieves Arise': Joseph Mountain's Revolutionary Atlantic and Consolidating Early National Connecticut," 2013, 498.

44. Block, Rape and Sexual Power in Early America, 2006, 32; Arthur, "The life, and dying speech of Arthur, a Negro man; who was executed at Worcester, October 2oth I768. For a rape committed on the body of one Deborah Metcalfe," America's Historical Imprints.

45. Slotkin, "Narratives of Negro Crime in New England," I973, 9 .

46. Hambleton, "Playing the Rogue," $2001,42$.

47. Block, Rape and Sexual Power in Early America, 2006, I67.

48. Slotkin, "Narratives of Negro Crime in New England," I973, I8; 22.

49. Block, Rape and Sexual Power in Early America, 2006, I7; Arthur, "The Life, and Dying Speech of Arthur, a Negro Man." 50. Arthur, "The Life, and Dying Speech of Arthur, a Negro Man."

51. Slotkin, "Narratives of Negro Crime in New England." I973, II.

52. Block, "Rape and Sexual Power in Early America." 2006, I49 53. Arthur, "The Life, and Dying Speech of Arthur, a Negro Man."

54. Arthur, "The Life, and Dying Speech of Arthur, a Negro Man."

55. Aaron Hutchinson, "Iniquity purged by mercy and truth. A sermon preached at Grafton, October 23d, I768. Being the Sabbath after the execution of Arthur, a Negro man, at Worcester, aged about 2I. For a rape," America's Historical Imprints. 56. Thaddeus McCarty, "The power and grace of Christ display'd to a dying malefactor. A sermon preached at Worcester October the twentieth, I768. Being the day of the execution of Arthur, a Negro of a [sic] about 2I years old, for a rape," America's Historical Imprints.

57. Cohen, "Social Injustice, Sexual Violence, Spiritual Transcendence." I999, 494.

58. Arthur, "The Life, and Dying Speech of Arthur, a Negro Man."

59. Block, Rape and Sexual Power in Early America, 2006, I7. 
9o. Young, "The last words, and dying speech, of Robert Young", America's Historical Imprints.

61. Foster, Sex and the Eighteenth Century Man, I999, 9I. 62. Young, "The Last Words, and Dying Speech, of Robert Young."

63. Young, "The Last Words, and Dying Speech, of Robert Young."

64. Foster, Sex and the Eighteenth Century Man, I999, I8. 65. Young, "The Last Words, and Dying Speech, of Robert Young."

66. Foster, Sex and the Eighteenth Century Man, I999, 63. 67. Block, Rape and Sexual Power in Early America, 2006, 212. 68. Lawrence, "Zuriel Waterman and the "Robert Young Broadsides: Intertextual Male Democracy in New England, I780," I997, I36.

69. Hambleton, "Playing the Rogue," 200I, 4I; Foster, Sex and the Eighteenth Century Man, 2007, 58.

70. Lawrence, "Zuriel Waterman and the Robert Young Broadsides," I997, I39.

7I. Block, Rape and Sexual Power in Early America, 2006, 57 72. Foster, Sex and the Eighteenth Century Man, 2007, 59. 73. Lawrence, "'Zuriel Waterman and the Robert Young Broadsides," I997, I54; Young, "The Last Words, and Dying Speech, of Robert Young"; Foster, Sex and the Eighteenth Century Man, 2007, 59.

74. Goodheart, "Rape, race and capital punishment in Connecticut to I830," 20I2, 77; Foster, Sex and the Eighteenth Century Man, 2007, xi.

75. Young, "The Last Words, and Dying Speech, of Robert Young."

76. Young, "The Last Words, and Dying Speech, of Robert Young."

77. Block, Rape and Sexual Power in Early America, 2006, 54 78. Robert Young, "The Dying Criminal: A Poem", America's Historical Imprints.

79. Young, "The Dying Criminal: A Poem."

8o. Young, "The Dying Criminal: A Poem."

8I. Brown and Brown, The Hanging of Ephraim Wheeler, 2005, 253 .

82. Brian Sheehen, Salem, January i6, I772. "An Account of the Life of Bryan Sheehen, This Day Executed in Salem, for Committing a Rape on the Body of Abial Hollowell, Wife of Benjamin Hollowell, of Marblehead ... Accordingly the Following Particulars Have Been Collected, Chiefly from His Own Mouth," America's Historical Imprints.

83. Cohen, "Social Injustice, Sexual Violence, Spiritual

Transcendence," I999, 483

84. Sheehen, "Salem, January I6, I772. An Account of the Life of Bryan Sheehen."

85. Slotkin, "Narratives of Negro Crime in New England, I675I800," I973, 8.

86. Sheehen, "Salem, January I6, I772. An Account of the Life of Bryan Sheehen."

87. Foster, Sex and the Eighteenth Century Man, 2007, 24-25.

88. Hambleton, "Playing the Rogue," 2001,58 ; Sheehen,

"Salem, January i6, I772. An Account of the Life of Bryan
Sheehen."

89. Sheehen, "Salem, January I6, I772. An Account of the Life of Bryan Sheehen."

90. Sheehen, "Salem, January I6, I772. An Account of the Life of Bryan Sheehen."

91. Sheehen, "Salem, January I6, I772. An Account of the Life of Bryan Sheehen."

92. Sheehen, "Salem, January I6, I772. An Account of the Life of Bryan Sheehen,";Rindfleisch, "What It Means to Be a Man," 2012,856

93. Brown and Brown, The Hanging of Ephraim Wheeler, 2005, 243.

94. Foster, Sex and the Eighteenth Century Man, 2007, 3I. 95. Foster, Sex and the Eighteenth Century Man, 2007, 75; Young, "The last words, and dying speech, of Robert Young"; Sheehen, "Salem, January I6, I772. An Account of the Life of Bryan Sheehen."; Arthur, "The life, and dying speech of Arthur, a Negro."

96. Block, Rape and Sexual Power in Early America, 2006, 230-23I; Foster, Sex and the Eighteenth Century Man, 2007, 58; Young, "The Last Words, and Dying Speech, of Robert Young"; Sheehen, "Salem, January i6, I772. An Account of the Life of Bryan Sheehen."; Arthur, "The Life, and Dying Speech of Arthur, a Negro Man."

97. Williams, "Rogues, Rascals and Scoundrels," i983, 7.

98. Foster, Sex and the Eighteenth Century Man, 2007, 4I. 99. Foster, Sex and the Eighteenth Century Man, 2007, 68-69. I00. Foster, Sex and the Eighteenth Century Man, 2007, 25. IOI. Block, Rape and Sexual Power in Early America, 2006, 2I5. I02. Williams, "Rogues, Rascals and Scoundrels," I983, 6; Young, "The Last Words, and Dying Speech, of Robert Young"; Sheehen, "Salem, January I6, I772. An Account of the Life of Bryan Sheehen.”; Arthur, "The Life, and Dying Speech of Arthur, a Negro Man."

I03. Foster, Sex and the Eighteenth Century Man, 2007, 88. I04. Foster, Sex and the Eighteenth Century Man, 2007, 5. 105. Foster, Sex and the Eighteenth Century Man, 2007, 7-IO. Io6. Foster, Sex and the Eighteenth Century Man 102, 2007; Young, "The Last Words, and Dying Speech, of Robert Young"; Sheehen, "Salem, January I6, I772. An Account of the Life of Bryan Sheehen."; Arthur, "The Life, and Dying Speech of Arthur, a Negro Man."

I07. Foster, Sex and the Eighteenth Century Man, 2007, 67. I08. U.S. Center for Disease Control, National Center for Injury Prevention and Control, National Intimate Partner and Sexual Violence Survey, I-2. 


\section{REFERENCES}

Arthur. "The Life, and Dying Speech of Arthur, a Negro Man; Who Was Executed at Worcester, October 2oth I768. For a Rape Committed on the Body of One Deborah Metcalfe." Printed and Sold [by Kneeland and Adams] in Milk-Street. I768.

Block, Sharon, and Omohundro Institute of Early American History \& Culture. Rape and Sexual Power in Early America. Chapel Hill: University of North Carolina Press, 2006.

Block, Sharon. "How Should We Look at Rape in Early America?" History Compass 4, no. 3 (June 2006): 603-I4.

Brown, Irene Quenzler, and Richard D. Brown. The Hanging of Ephraim Wheeler: A Story of Rape, Incest, and Justice in Early America. Cambridge, Mass.: Belknap Press, 2005 .

Cohen, Daniel A. "Social Injustice, Sexual Violence, Spiritual Transcendence: Constructions of Interracial Rape in Early American Crime Literature, I767-18I7." The William and Mary Quarterly 56, no. 3 (July I, I999): 48I526. doi:10.2307/2674559.

Ditz, Toby L. “The New Men's History and the Peculiar Absence of Gendered Power: Some Remedies from Early American Gender History." Gender \& History I6, no. I (April 2004): I-35.

Foster, Thomas. Sex and the Eighteenth-Century Man: Massachusetts and the History of Sexuality in America. Boston: Beacon Press, 2007.

Goodheart, Lawrence B. and Peter P. Hinks. "'See the Jails Open and the Thieves Arise': Joseph Mountain's Revolutionary Atlantic and Consolidating Early National Connecticut." Atlantic Studies, Io no. 4 (December 20I3): 497-527.

Goodheart, Lawrence B. "Race, Rape and Capital Punishment in Connecticut to I830." Patterns of Prejudice 46, no. I (February 2012): 58-77.

Hambleton, Else L.. “'Playing the Rogue:' Rape and Issues of Consent in Seventeenth Century Massachusetts." In Sex without Consent: Rape and Sexual Coercion in America, edited by Merril Smith. New York: New York University Press, 200I.
Hutchinson, Aaron. "Iniquity Purged by Mercy and Truth. A Sermon Preached at Grafton, October 23d, I768. Being the Sabbath after the Execution of Arthur, a Negro Man, at Worcester, Aged about 2I. For a Rape.” Thomas and John Fleet, October 23, I768. America's Historical Imprints. http://infoweb.newsbank.com.proxy.bc.edu/iw-search/ we/Evans/?p_product=EAIX\&p_theme=eai\&p_nbid=B6 -C57CUMTQyMzcwMTczMS44MDAzOTQ6MToxMjox MzYuMTY3LjMuMzY\&p_action=doc\&p_docnum=4\&p_ queryname=2\&p_docref=v2: oF2BIFCB879Bo99B@ EAIX-oF2FD2DF7224DA6o@II299-@I.

Kerber, Linda K., Nancy F. Cott, Robert Gross, Lynn Hunt, Carroll Smith-Rosenberg, and Christine M. Stansell. "Beyond Roles, Beyond Spheres: Thinking about Gender in the Early Republic." The William and Mary Quarterly 46, no. 3 (July I, I989): $565-85$.

Lawrence, Keith. "Zuriel Waterman and the 'Robert Young Broadsides': Intertextual Male Democracy in New England, I780." Early American Literature 32, no. 2 (January I, I997): I35-68.

Leverington, Elizabeth Kukorelly. "DOMESTICATING THE HERO: NORMATIVE MASCULINITY IN 'ROBINSON CRUSOE' AND 'PAMELA, OR VIRTUE REWARDED." Hungarian Journal of English and American Studies (HJEAS) I3, no. I/2 (April I, 2007): 147-64.

Lindemann, Barbara S. “To Ravish and Carnally Know': Rape in Eighteenth-Century Massachusetts." Signs Io, no. I (October I, I984): 63-82.

Lindman, Janet Moore. "Acting the Manly Christian: White Evangelical Masculinity in Revolutionary Virginia." The William and Mary Quarterly 57, no. 2 (April I, 2000): 393-4I6.

McCarty, Thaddeus. "The Power and Grace of Christ Display'd to a Dying Malefactor. A Sermon Preached at Worcester October the Twentieth, I768. Being the Day of the Execution of Arthur, a Negro of a [sic] about 2I Years Old, for a Rape." Printed and sold by Kneeland and Adams, next to the treasurer's office, in Milk-Street, I768.

Osborne, Jeff. "Constituting American Masculinity." American Studies 49, no. 3/4 (October I, 2008): III-32.

Rindfleisch, Bryan C. “'What It Means to Be a Man': Contested Masculinity in the Early Republic and 
Antebellum America"." History Compass Io, no. II (November I, 20I2): 852-65. doi:IO.IIII/hic3.I2005.

Sheehen, Bryan. "Salem, January I6, I772. An Account of the Life of Bryan Sheehen, This Day Executed in Salem, for Committing a Rape on the Body of Abial Hollowell, Wife of Benjamin Hollowell, of Marblehead ... Accordingly the Following Particulars Have Been Collected, Chiefly from His Own Mouth." Daniel and Robert Fowle, January I6, I772. America's Historical Imprints. http://infoweb.newsbank.com.proxy.bc.edu/ iw-search/we/Evans/?p_product=EAIX\&p_theme=eai\&p_ nbid=B60C 57CUMTQyMzcwMTczMS 44MDAzOTQ 6MToxMjoxMzYuMTY3LjMuMzY\&p_action=doc\&p_ queryname=2\&p_docref=v2:oF2BIFCB879Bo99B@ EAIX-oF2F827682E4DC28@I2559-@I.

Slotkin, Richard. "Narratives of Negro Crime in New England, I675-I800.” American Quarterly 25, no. I (March I, I973): 3-3I.

Snyder, Terri L. "Sexual Consent and Sexual Coersion in Seventeenth- Century Virginia." In Sex without Consent: Rape and Sexual Coercion in America, edited by Merril Smith. New York: New York University Press, 200I.

U.S. Center for Disease Control, National Center for Injury Prevention and Control. National Intimate Partner and Sexual Violence Survey. By M.C. Black, et al. Atlanta, Georgia: The National Center for Injury Prevention and Control, 20Io.

Williams, Daniel E. "Rogues, Rascals and Scoundrels: The Underworld Literature of Early America." American Studies 24, no. 2 (Summer I983): 5-I9.

Young, Robert. "The Dying Criminal: A Poem," November II, I779. America's Historical Imprints. http:// infoweb.newsbank.com.proxy.bc.edu/iw-search/we/ Evans $/$ ?p_product=EAIX\&p_theme=eai\&p_nbid=B60C 57CUMTQyMzcwMTczMS44MDAzOTQ6MToxMjoxM zYuMTY3LjMuMzY\&p_action=doc\&p_docnum=9\&p_ queryname=2\&p_docref=v2:oF2BIFCB879Bo99B@ EAIX-oF2F822C63C9F8D8@43738-@I.

Young, Robert. “The Last Words, and Dying Speech, of Robert Young," November II, I779. America's Historical Imprints. http://infoweb.newsbank.com.proxy.bc.edu/iw-search/ we/Evans/?p_product=EAIX\&p_theme $=$ eai\&p_nbid=B6 oC57CUMTQyMzcwMTczMS44MDAzOTQ6MToxMjox
MzYuMTY3LjMuMzY\&p_action=doc\&p_docnum=II\&p_ queryname=2\&p_docref=v2:oF2BIFCB879Bo99B@ EAIX-oF30I4298B47AA30@i6688-@I. 